\title{
Wyoming Law Journal
}

Volume 1 | Number 1

Article 10

December 2019

Necrology Committee Report

Wyoming State Bar

Follow this and additional works at: https://scholarship.law.uwyo.edu/wlj

\section{Recommended Citation}

Wyoming State Bar, Necrology Committee Report, 1 WYo. L.J. 43 (1946)

Available at: https://scholarship.law.uwyo.edu/wlj/vol1/iss1/10

This Special Section is brought to you for free and open access by Law Archive of Wyoming Scholarship. It has been accepted for inclusion in Wyoming Law Journal by an authorized editor of Law Archive of Wyoming Scholarship. 
RESOLVED, that the Wyoming State Bar in annual meeting, assembled at Casper, Wyoming, urges the President and Congress of the United States to take the lead in seeking to pursuade the nations to grant to the United Nations jurisdiction and power to enact and enforce throughout the territories of all nations, laws and regulations to control the development and use of atomic energy, to supplement and obtain existing agreements for the protection and health and welfare; and as rapidly as possible extend the policy of world government to other fields which affect or may affect relations between nations and the peace of the world.

BE IT Further Resolved that the Secretary of the Wyoming Bar Association send a copy of this resolution to the President of the United States and to each member of Congress.

I move the adoption of the report of the Committee.* *NOTE: This motion was tabled.

\section{NECROLOGY COMMITTEE REPORT}

The Necrology Committee reported that the following members had passed away since the last meeting:

L. E. Armstrong, Rawlins

Charles L. Brome, Basin

Carl E. Geiger, Casper

John G. Hutton, Sheridan 